УДК 351.824 .11

DOI https://doi.org/10.32837/yuv.v0i2.1704

\author{
Л. Дешко, \\ доктор юридичних наук, професор, \\ завідувач кафедри міжнародного публічного права \\ Київського національного торговельно-економічного університету
}

\title{
ОКРЕМІ АСПЕКТИ РЕАЛІЗАЦІЇ ДЕРЖАВНОЇ ПОЛІТИКИ У СФЕРІ ЕЛЕКТРОЕНЕРГЕТИКИ
}

Забезпечення сталого розвитку електроенергетичного сектору та ринку електричної енергії зокрема є особливо важливим на етапі входження країни до світового економічного простору, оскільки від стану даного сектору економіки значною мірою залежать ступінь економічної та політичної незалежності країни, темп виходу країни з кризового стану та стан їі національної безпеки.

Неефективне внутрішнє споживання електроенергії підвищує рівень залежності від країн-експортерів і поглиблює проблему енергетичної безпеки країни за рівнем імпортозалежності понад $51 \%$ за нереалізованого потенціалу енергозбереження в Україні до $48 \%$ від обсягу споживаних ресурсів.

Український ринок електричної енергіi, як і більшість світових аналогічних ринків, перебуває у процесі динамічного розвитку, який зумовлений різними стадіями його реформування. Варто зазначити, що розвиток як світової, так і національної енергетичної сфери $є$ одним із ключових напрямів державної політики, ефективна реалізація якої забезпечить сталий розвиток суспільства.

Зазначимо, що енергетика на сучасному етапі $€$ основою розвитку економіки. Міжнародне енергетичне агентство (MEA, IEA) у роботі «Огляд Світової енергетики 2017» (World Energy Outlook, WEO 2017) прогнозує інтенсивне зростання економіки країн та регіонів світу на наступні 20 років. В основу прогнозу покладено зростання попиту на первинну енергію за регіонами та країнами світу, зумовлене такими ключовими чинниками, як: середньорічне зростання на $3,4 \%$ світової економіки; зростання населення із сьогоднішніх 7,4 млрд осіб до понад 9 млрд осіб у 2040 р. Споживання енергії на душу населення за середньорічного темпу зростання в $0,7 \%$ до 2040 р. збільшиться на $30 \%$. Відповідно до висновків прогнозу, МЕА зазначено значне зростання динаміки попиту на первинну енергію за регіонами та краінами світу. При цьому регіональні тенденціі істотного зростання визначатимуть Китай, Індія, Бразилія та Близький Схід. Аналітичні дослідження та прогнозні оцінки визначають загальноекономічні орієнтири для формування національних стратегій і програм розвитку окремих галузей, регіонів та країн [1].

Світова економічна криза зумовила певні негативні явища в енергетиці краіни. Показово, що, за даними Державної служби статистики України, Індекс промислової продукції (економічний показник, що характеризує динаміку фізичного обсягу виробництва добувної, обробної промисловості та ЖКГ) у промисловості у цілому становив у 2008 p. 94,8\% (до попереднього року), у 2009 р. - 78,1\% (до попереднього року), у 2010 та 2011 рр. відбулася певна стабілізація, але в 2012 р. аналізований показник знову виявився негативним - 98,2\% (до попереднього року) [2]. Про наявність ознак кризи свідчать також показники виробництва основних видів промислової продукції, де за більшістю товарних позицій так і не вдалося досягнути передкризового рівня в натуральному вимірі [3]. Водночас обсяги інвестицій в електроенерге- 
тику залишилися на високому рівні. Так, за офіційними даними, у 2010 р. обсяг інвестицій в електроенергетичну галузь становив 9279,9 млн грн, у 2014 р. 22895,0 млн грн, у 2018 р. $-41783,9$ млн грн, у 2019 р. - 75612,3 млн грн [4]. Вожночас Китай лише у 2018 р. проінвестував національну електроенергетику загальним обсягом 91,2 млрд дол, у США цей показник становив майже 43 млрд дол. [5]. Таким чином, перед органами публічної адміністрації стоїть дуже важливе стратегічне завдання створення сприятливих умов для збільшення обсягів інвестицій у національну електроенергетику. Отже, питання щодо визначення сутності та змісту державної політики в електроенергетиці є вкрай актуальними та потребують додаткового наукового осмислення.

Різні аспекти адміністративно-правового регулювання ринку електричної енергії розглядалися у працях В.Б. Авер'янова, I.О. Анохіної, Г.І. Балюка, А.І. Берлача, М.С. Блохіна, Ю.В. Ващенко, В.К. Колпакова, М.А. Кордюкової, О.В. Кузьменко, О.П. Рябченко та ін. Разом із тим питання щодо змісту державної політики у сфері електроенергетики досліджено фрагментарно, к межах широкої адміністративно-правової проблематики.

Мета статті полягає у тому, щоб на основі системного аналізу галузевого законодавства, наукових поглядів вітчизняних учених, а також норм національного законодавства визначити сутність державної політики у сфері електроенергетики.

Цікаво зазначити, що державна політика у сфері електроенергетики $€$ основним інструментом регулювання суспільних відносин у даній сфері.

Загальновідомо, що державна політика 3 юридичного погляду становить комплексне явище зі специфічними змістом і структурою. Поняття «державна політика» у «Великому тлумачному словнику сучасної української мови» визначається як: по-перше, діяльність органів державної влади та державного управління, що відображає суспільний лад та економічну структуру країни; по-друге, діяльність партій та інших організацій, об’єднань громадян, зумовлена їхніми інтересами та метою [11, с. 758]. Не вдаючись у детальний аналіз наукових поглядів щодо визначення поняття «державна політики», слід навести думку Ю.В. Якимець, яка вважає, що державну політику доцільно розглядати як:

- «транспарентний» процес прийняття політичних, управлінських рішень;

- цілеспрямований вплив, який здійснюється структурами публічної влади;

- програма, що містить стратегії розвитку держави;

- визначений курс дії публічної влади [12, с. 83].

Зазначимо, що наведена думка в повному обсязі відображає зміст сучасної державної політики, адже, дійсно, державна політика формується та реалізується державою у контексті діяльності органів публічного адміністрування та під час реалізації їніх повноважень; або йдеться про галузеву політику.

У Законі України «Про ринок електричної енергії» встановлено основні засади державної політики у сфері електроенергетики та безпеки постачання, водночас законодавець не наводить визначення даного поняття. Тому залишається не з'ясованим, що таке державна політика відносно електроенергетики та безпека постачання, які особливості їй притаманні.

Загалом під державною політикою слід розуміти комплекс правових, адміністративних та економічних заходів держави, спрямованих на поширення та активізацію процесів у будь-якій сфері публічного адміністрування [6]. Деякі вчені вважають, що до наведених елементів зміст державної політики повинен включати: цілеспрямоване законодавство, підпорядковане певній ідеї, створення інфраструктури, що забезпечить сталий розвиток галузі, формування суспільної підприємницької ідеології, протекціонізм [7, с. 33]. Безумовно, наведені позиції створюють відповідне підгрунтя для проведення наукових досліджень із 
цього питання. Разом із тим, виходячи зі змісту Закону України «Про ринок електричної енергії, електроенергетична галузь та ринок електричної енергії зокрема включають у себе значний спектр суспільних відносин, що насамперед пов'язані з виробництвом, передачею, розподілом, купівлею-продажем, постачанням електричної енергії, забезпеченням надійного, безпечного постачання електричної енергії тощо.

Таким чином, на нашу думку, державна політика у сфері електроенергетики - це система нормативно-закріплених заходів, що визначають зміст діяльності органів публічної адміністрації щодо ефективної реалізації відносин із приводу виробництва, передачі, розподілу, купівлі-продажу, постачання електричної енергії, забезпечення надійного, безпечного постачання електричної енергіі, забезпечення ефективного функціонування ліквідного ринку електричної енергіі, а також створення сприятливих умов для залучення інвестицій із метою забезпечення сталого розвитку електроенергетичної галузі. Відповідно до вищевикладеного, пропонується доповнити ст. 5 Закону України «Про ринок електричної енергії.

Розглядаючи зміст державної політики у сфері електроенергетики, необхідно зауважити, що у світі функціонують різні моделі політики держави щодо зазначеної сфери. Аналіз зарубіжного досвіду свідчить, що нині умовно існують такі ї моделі: «жорстко регламентованого» регулювання діяльності всіх учасників ринку електричної енергіï (США), лібералізація ринку електричної енергії (Великобританія), централізація публічного адміністрування ринку електричної енергії (Франція). Наявність такої кількості моделей насамперед пов'язана з тим, що зміст державної політики у сфері електроенергетики є багатогранним і охоплює не лише послідовність етапів ї розроблення, а й детальне розроблення ї функціонального і тимчасового аспекту.

Варто зазначити, що ст. 5 Закон України «Про ринок електричної енер- гії визначає, що державна політика в електроенергетиці спрямована на:

- забезпечення надійного, безпечного постачання електричної енергіі;

- створення умов для ефективного функціонування ліквідного ринку електричної енергії та його розвитку;

- забезпечення умов та застосування заходів для розвитку енергоефективності в електроенергетиці, управління попитом та енергозаміщення;

- сприяння виробництву електричної енергії 3 альтернативних джерел енергіï та розвитку розподіленої генерації й обладнання для акумулювання енергіі;

- захист навколишнього природного середовища; створення умов для залучення інвестицій в електроенергетику, спрощення доступу до інформації та адміністративних процедур;

- стимулювання застосування інноваційних технологій;

- захист прав споживачів; інтеграцію ринку електричної енергії на регіональному та загальноєвропейському рівнях [8].

Варто зазначити, що аналіз правозастосовчої практики відповідних суб'єктів публічного адміністрування на ринку електричної енергії свідчить, що під час реалізації визначених у ст. 5 Закону напрямів виникли такі складнощі:

- технологічні, а саме: забезпечення ефективного внутрішнього споживання; забезпечення оновлення промислових потужностей;

- організаційні, а саме: підвищення прозорості державних фінансів і розширення аналізу стану електроенергетичного сектору економіки країни; забезпечення прозорості приватизації об'єктів електроенергетики; забезпечення впровадження ефективних заходів протидії корупції в електроенергетичному секторі; неефективне виконання державою своїх обов'язків щодо соціального захисту населення; прозорість та простота реалізації адміністративних процедур на ринку електричної енергії (наприклад, реєстрація або ліцензування); прозорість діяльності посадових осіб контролюючих суб'єктів на ринку електричної енергіі; 
- структурно-інституційні, а саме: забезпечення політичної стабільності, прозорої та стабільної роботи всіх гілок влади, їх можливість співпрацювати та «домовлятися» між собою.

Розглянемо окремі з наведених чинників. Так, зокрема, прозорість та простота реалізаціі адміністративних процедур на ринку електричної енергії $є$ однією з умов розвитку даного сектору економіки. Слід зазначити, що значна кількість експертів зазначає про необхідність та важливість спрощення існуючих адміністративних процедур у сфері електроенергетики. Це насамперед відноситься до процедури ліцензування. Так, відповідно до Закону України «Про ринок електричної енергії», під ліцензування підпадає: господарська діяльність із виробництва, передачі, розподілу електричної енергіі, постачання електричної енергії споживачу, трейдерська діяльність, здійснення функцій оператора ринку та гарантованого покупця [8]. Аналіз діяльності Національної комісіі, що здійснює державне регулювання у сферах енергетики та комунальних послуг свідчить, що кожного року кількість ліцензій на ринку електричної енергії скорочується. Так, у 2015 р. було видано майже 630 ліцензій на здійснення господарської діяльності на ринку електричної енергіі, у 2016 р. цей показник становив майже 350 ліцензій, у 2017 р. - 402. Водночас кількість перевірок також залишається значною. Так, у 2017 р. Національною комісію, що здійснює державне регулювання у сферах енергетики та комунальних послуг, було здійснено 240 перевірок щодо дотримання ліцензіатами вимог ліцензійних умов, однак у 2018 р. цей показник становив 251 [9]. Водночас, думку окремих іноземних фахівців щодо скасування ліцензування слід запроваджувати «виважено», адже загальновідомо, що електроенергетика $€$ стратегічною галуззю національної економіки і від ефективності іiі функціонування напряму залежить стан функціонування окремих галузей національної економіки та населення країни у цілому.
Окрім того, під час здійснення ліцензування господарської діяльності на ринку електричної енергії (наприклад, щодо виробництва електричної енергї або ї передачі) відбувається попередній державний контроль останнього.

Не менш велике значення щодо ефективної реалізації державної політики має рівень корупції в електроенергетичній галузі. Зазначимо, що даний показник суттєво впливає на рівень інвестиційного клімату в країні. Характеризуючи рівень корупції у державі як чинника, що визначає сприятливість інвестиційного клімату, варто зауважити, що, безумовно, рівень корупції в Україні, на жаль, залишається істотним. Окрім того, результати дослідження, яке було проведене GfK у 2018 р., свідчать, що $91,0 \%$ респондентів уважають, що корупція $€$ широко розповсюдженим явищем в Україні; 30\% українців знають про скандальну схему «Роттердам+». Ця схема вже обійшла схему «РосУкрЕнерго», про яку знає 25\% українців. Де-факто у «Роттердам+» найбільша впізнаваність із діючих сьогодні корупційних схем; 79\% українців уважають, що корупція в електроенергетиці призводить до завищених цін та тарифів; $45 \%$ українців уважають, що корупція в електроенергетиці призводить до низької якості відповідних товарів та послуг; 66\% українців уважають, що корупція у сфері електроенергетики $є$ однією з найбільших проблем держави та суспільства загалом; 19\% українців уважають, що корупція у сфері енергетики, у тому числі в електроенергетиці, є найбільшою проблемою України [10]. Так, дійсно, такі показники не можуть сприяти формуванню позитивного інвестиційного клімату в енергетичному секторі економіки держави.

Роблячи підсумок, слід зазначити, що нині для сучасної державної політики у сфері електроенергетики необхідними $€$ розроблення та прийняття «діючого» стратегічного плану розвитку національної електроенергетики, що має містити конкретні дієві для нашої країни шляхи та механізми проведення 
реформ, у тому числі у сфері електроенергетики. Проте для реальної активізації дій лише прийняття зазначеної програми є недостатнім, оскільки діяльність органів публічної адміністрації повинна бути спрямована: по-перше, на створення нормативно-правової основи для заохочення вкладення довгострокових фінансових інвестицій; по-друге, на вдосконалення адміністративних процедур в електроенергетиці; по-третє, на формування системи стимулів інвестиційної діяльності в електроенергетиці.

Окрім цього, встановлено, що державна політика у сфері електроенергетики - це система нормативно закріплених заходів, що визначають зміст діяльності органів публічної адміністрації щодо ефективної реалізації відносин із приводу виробництва, передачі, розподілу, купівлі-продажу, постачання електричної енергії, забезпечення надійного, безпечного постачання електричної енергії, забезпечення ефективного функціонування ліквідного ринку електричної енергії, а також створення сприятливих умов для залучення інвестицій із метою забезпечення сталого розвитку електроенергетичної галузі. Відповідно до вищевикладеного, пропонується доповнити ст. 5 Закону України «Про ринок електричної енергії.

у статті детально проаналізовано довідкову, наукову та навчальну літературу та норми чинного законодавства з метою визначення сутності та змісту державної політики у сфері електроенергетики. У результаті дослідження встановлено, щзо нині в науковій літературі та чинному законодавстві відсутній єдиний підхід до визначення даного поняття. Автором наголошено, що однозначність понятійного апарату впливае на ефективність правозастосовної практики органів публічної адміністраціі. Зазначено, що нині для сучасної державної політики у сфері електроенергетики необхідними є розроблення та прийняття «діючого» стратегічного плану розвитку національної електроенергетики, що має містити конкретні дієві для нашої країни иляхи та механізми проведення реформ, у тому числі у сфері електроенергетики. Проте для реальної активізації дій лише прийняття зазначеної програми є недостатнім, оскільки діяльність органів публічної адміністраціi повинна бути спрямована: по-перше, на створення нормативно-правовоі бази для заохочення вкладення довгострокових фінансових інвестицій; по-друге, на вдосконалення адміністративних процедур в електроенергетиці; по-третє, на формування системи стимулів інвестиційної діяльності в електроенергетиці. Обтрунтовано, щзо державна політика у сфері електроенергетики - иее система нормативно закріплених заходів, щзо визначають зміст діяльності органів публічної адміністраціі щзодо ефективної реалізаціі відносин із приводу виробниитва, передачі, розподілу, купівлі-продажу, постачання електричної енергї, забезпечення надійного, безпечного постачання електричної енергї, забезпечення ефективного функціонування ліквідного ринку електричної енергї, а також створення сприятливих умов для залучення інвестицій із метою забезпечення сталого розвитку електроенергетичної галузі. Окрему увагу приділено характеристиці складнощів під час реалізації державної політики у сфері електроенергетики, зокрема організаційним, структурно-інституційним, технологічним.

Ключові слова: державна політика, політики, електрична енергія, зміст, сфера, електроенергетика.

Deshko L. Some aspects of the implementation of state policy in the field of electricity

This article analyzes in detail the reference, scientific and educational literature and current legislation in order to determine the nature and content of state policy in the field of 
electricity. As a result of the research it was established that currently in the scientific literature and current legislation there is no single approach to defining this concept. The author emphasizes that the unambiguity of the conceptual apparatus affects the effectiveness of law enforcement practice of public administration.

It is noted that currently for the modern state policy in the field of electricity it is necessary to develop and adopt a "valid" strategic plan for the development of national electricity, which should contain specific effective for our country ways and mechanisms of reforms, including in the field of electricity. However, for the actual intensification of actions, the adoption of this program alone is insufficient, as the activities of public administration bodies should be aimed at: first, creating a regulatory framework to encourage longterm financial investments; secondly, the improvement of administrative procedures in the power industry; third, the formation of a system of incentives for investment in electricity.

It is substantiated that the state policy in the field of electricity is a system of normatively established measures that determine the content of the activities of public administration bodies for the effective implementation of relations concerning production, transmission, distribution, purchase and sale, electricity supply, ensuring reliable, secure electricity supply. ensuring the efficient functioning of the liquid electricity market, as well as creating favorable conditions for attracting investment, in order to ensure the sustainable development of the electricity industry. Particular attention is paid to the characteristics of difficulties in the implementation of state policy in the field of electricity, in particular organizational, structural and institutional, technological.

Key words: state policy, policies, electric energy, content, sphere, electric power.

\section{Література}

1. Аналіз тарифо- та иіноутворення на електроенергію у країнах ЄC та ОЕСР. Системи стимулюючого тарифоутворення. URL : https://ua.energy/wp-content / uploads/2018/10/3.-Taryfo_tsinoutv_ elektroen.pdf.

2. Індекси промислової продукиіі за 2007-2012 роки в Україні - офіційні дані Державної служби статистики України. URL : http://www.ukrstat.gov.ua/ operativ / operativ2007/pr/prm_ric/prm_ ric_u/ipv2006_u.html.

3. Виробництво основних видів промислової продукції за 2003-2011 роки - офіційні дані Державної служби статистики України. URL:http: / / www.ukrstat.gov.ua/ operativ / operativ2007/pr/prm_ric/prm_ ric_u/ipv2006_u.html.

4. Капітальні інвестиції за видами економічної діяльності промисловості за 2010-2019 рокu. URL : http://www. ukrstat.gov.ua/operativ/operativ2013/ibd/ $i b d \_r i k / i b d \_u / k i \_r i k \_p \_u \_e \_b e z . h t m$.

5. Откуда берет средства «зеленая» енергетика. URL : https://trends.rbc.ru/ trends / green/5d64f35a9a794733fce7791a.

6. Державне регулювання інвестиційної діяльності: Роль держави в інвестиційній diяльності. URL : http://ecolib.com.ua/ article.php?book $=11$ \&article $=1088$.

7. Денисенко М.П., Гречан А.П. Інвестиційний клімат України та напрями його подальшого покращення. Проблеми науки. 2005. № 12. C. 32-39.

8. Про ринок електричної енергї : Закон України від 13.04.2017 № 2019-VIII. Відомості Верховної Ради України. 2017. № 27-28. Cm. 312 .

9. Звіт про результати діяльності Національної комісії, що здійснюе державне регулювання у сферах енергетики та комунальних послуг у 2015, 2016, 2017 роках. URL : https: / / wwe.nerc.gov.ua/ index.php / data/filearch / Materialy_ zasidan $/ 2017 /$ serpen $/$ ? id $=31942$.

10. У Комітеті з питань запобігання i протидї корупиії відбувся круглий стіл щодо впливу на тарифи корупціï та монополізації енергетики. URL : https: / / wшш. rada.gov.ua/news / Novyny / 170339.html.

11. Великий тлумачний словник сучасної української мови / гол. ред. В.Т. Бусел. Київ ; Iрпінь : Перун, 2005. 1728 с.

12. Якимець Ю.В. Публічне адміністрування сфери культури : дис. ... канд. юрид. наук : 12.00.07. Київ, 2012. 202 c. 